\title{
Characterization and identification of clay-material provenance from Bayat ceramic home industry in Klaten, Central Java, Indonesia
}

\author{
Nugroho Imam Setiawan ${ }^{1 *}$, Indra Perdana $^{2}$,Vidya Syarifah ${ }^{1}$, Pra Cipta Buana $^{2}$, Milzam Dzulfiqar Setyowiyoto ${ }^{1}$, Rizki \\ Istinanda $^{2}$, Didit Hadi Barianto ${ }^{1}$, and Chusni Ansori ${ }^{1,3}$ \\ ${ }^{1}$ Geological Engineering Department, Engineering Faculty, Universitas Gadjah Mada, DI Yogyakarta, 55281, Indonesia \\ ${ }^{2}$ Chemical Engineering Department, Engineering Faculty, Universitas Gadjah Mada, DI Yogyakarta, 55281, Indonesia \\ ${ }^{3}$ Research Centre for Geotechnology, Indonesian Institute of Sciences, J1. Sangkuriang, Kompleks LIPI, Bandung, 40135, Indonesia
}

\begin{abstract}
Bayat Ceramic Home Industry in Klaten, Central Java, Indonesia is produced from three primary locations of Melikan, Paseban, and Ndolon. The clay-sources of the ceramic were mined from Bayat and surrounding areas, which is geologically named Jiwo Hills. Characterization and identification of clay material sources of the ceramic products from these areas were done in to understand the correlation between provenance and production processes. This paper presents the first contribution on Bayat ceramic by investigating the mineralogical composition using petrography and X-Ray Diffraction (XRD) analyses. Understanding the characteristics and compositions of clay material source of ceramic in Bayat can be used to determine other clay source locations or quarry that have the similar characteristics to current claymaterials. The clay minerals of ceramic products from Melikan and Paseban are halloysite, smectite, and kaolinite, while from Ndolon are smectite and kaolinite. Mono- and poly-crystalline quartz with the lithic fragments of phyllites were found in Melikan and Paseban ceramics. Ceramic from Ndolon is rich in plagioclase and lithic andesite. Clay provenance of ceramic products from Melikan and Paseban might be derived from weathered low-grade metamorphic and igneous rocks from West Jiwo Hills. While from Ndolon might be derived from weathered igneous or volcanic rocks from Kebo-Butak Formation. The amorphous silica found in the ceramic from Melikan, Paseban, and Ndolon suggests the firing process between $700-800^{\circ} \mathrm{C}$. Thus, our results provide the database of clay source characteristics to determine the following possible clay-quarry location for the raw materials of ceramic products in this location.
\end{abstract}

\section{Introduction}

The Bayat ceramic home industry in Klaten, Central Java, Indonesia, has been known local to international markets for their quality and characteristics [1]. Some of the physical characteristics of the ceramic from Bayat is blackish-shine brown in color and smooth surface. The Bayat ceramics are mainly crafted by the residents of Melikan and Paseban Villages, which administratively belong to Wedi and Bayat Subdistricts, respectively. According to historical stories among the villagers, the ceramic industry in Bayat has existed for 600 years ago with the production techniques were studied for generations [2]. They created their unique traditional techniques of oblique ceramic wheel to shaping their ceramic [3]. The clay-sources of the ceramic also mined from their surrounding areas, which geologically named Jiwo Hills.

The Jiwo Hills in Bayat is one of the areas that crop out the basement rocks in Central Java [4, 5]. This area is an isolated hill, which approximately has $30 \mathrm{~km}^{2}$ expose metamorphic, igneous, and sedimentary rocks ranging from Cretaceous to Neogene ages $[4,6]$. Most of the rocks in this area are highly weathered, which is indicated by the soil layer's thickness and alluvium deposit. Therefore, the clay-materials from the weathering processes are plenty.

The Bayat ceramic home industry in this area is mainly produced from three areas of Melikan, Paseban, and Ndolon. Administratively, Ndolon is a hamlet part of the Paseban Village. The Melikan and Paseban are located on the northern side, while Ndolon is located on the southern side of the Bayat-Cawas Street (Figure 1). Craftsmen in these areas follow their predecessors to determine the location of the raw clay-materials. They do not have detailed information of the ceramic clayprovenance composition. Understanding the composition is important as a guide to determine the future location of clay-quarry if this current quarry location is mined out.

This research aims to characterize and identify clay material sources of the ceramic products from these areas to understand the correlation between provenance and production processes. The results of this contribution are important to be used as suggestions for formulating and determining the possible source of the raw material for ceramic and other policies related to the

\footnotetext{
* Corresponding author: nugroho.setiawan@ugm.ac.id
} 
development of the ceramic industry in Bayat in the future.

\section{Regional geology}

Jiwo Hills located in the Bayat area, which approximately $45 \mathrm{~km} \mathrm{NE}$ from Yogyakarta (Figure 1). The Jiwo Hills is divided by the NE-SW trend of Dengkeng River into two areas of West and East Jiwo (Figure 1). The basement and older rocks exposed in this area are low-grade metamorphic rocks, mainly composed of various phyllites, marble, and quartzite with the age of Early Cretaceous [5,6].

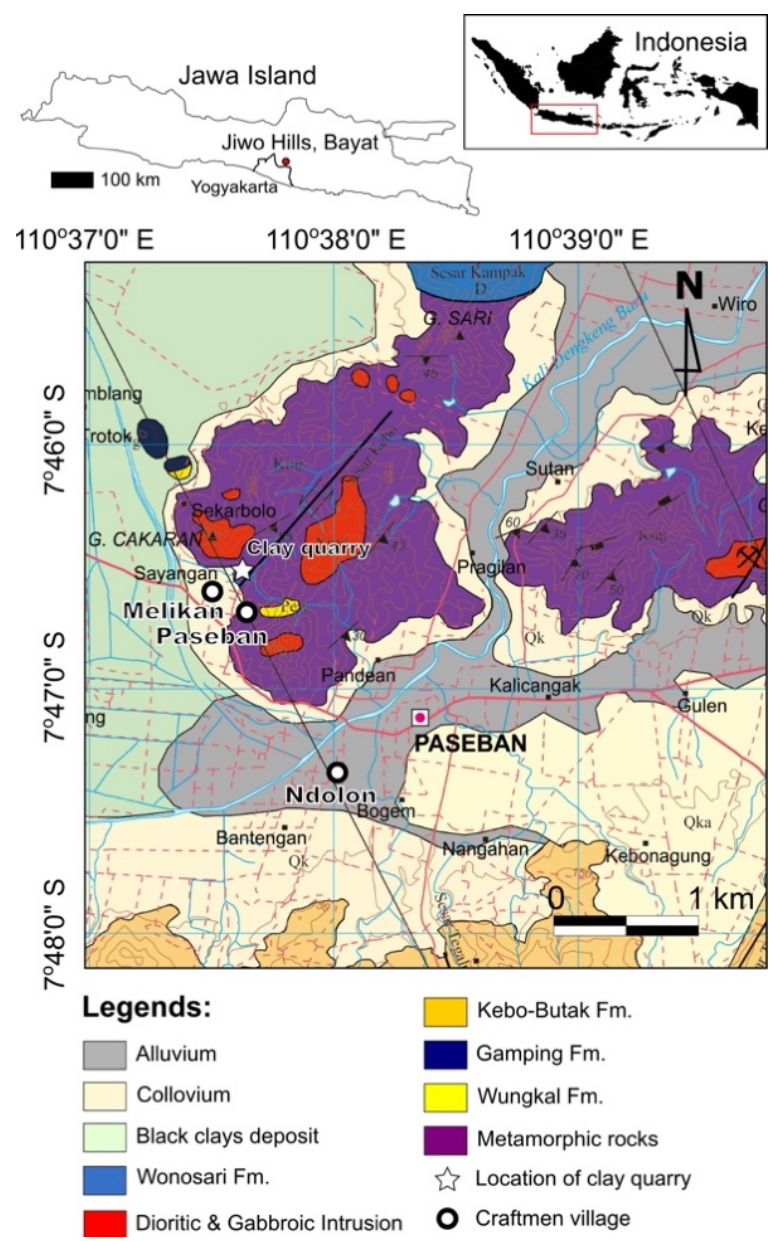

Fig. 1. Research location and geological map of Jiwo Hills. Modified from Barianto et al. [4].

Barianto et al. [5] suggest that Eocene sedimentary rocks of Wungkal and Gamping Formations (quartz sandstone and nummulitic limestone), and Oligocene Early Miocene volcaniclastic rocks of Kebo-Butak Formation, were unconformably overlain the metamorphic rocks. Moreover, the Oligo-Miocene of dioritic to gabbroic igneous rocks intruded all previously settled formations in this area. During Middle to Late Miocene, carbonate rocks of the Wonosari Formation conformably overlain the volcaniclastics Kebo-Butak Formation. Four general major faults with the orientations of NE-SW, N-S, NW-SE, and E-W were recognized in this area [5].

Being in the tropical country with the history of exhumation and uplifting processes since Cretaceous to
Quarternary, this area was significantly experiencing a denudation and weathering processes. It is indicated by difficulty to get fresh outcrop and by characteristics of the thickness of the soil layer and alluvium deposit (Figure 1).

\section{Methodology}

Fieldwork and interview with the craftsmen in Melikan, Paseban, Ndolon, and surrounding areas were performed to collect the primary data for this research. In-depth interviews were conducted with several craftsmen, including Mr. Rusmantoro from Melikan, Mr. Budi from Paseban, and Mr. Kawit from Ndolon.

Generally, there are three materials related to the ceramic product, which are (1) clay-sized from the quarry, (2) mixed-material between clay and sand, and (3) ceramic products. The clay-sized raw materials of the Melikan and Paseban areas are derived from the same quarry, which derived from the alluvium deposit (Figures $1 \& 2 \mathrm{a}$ ). We collected five samples of claysized raw materials from this area.

Ceramic products from Ndolon having different quarry locations from Melikan and Paseban. Based on the information from the craftsmen, the clay-sources materials were collected from a quarry in the Gunung Kidul area, southern part of the Bayat. In this recent paper, we could not get samples directly from the quarry. However, we analyzed 1 sample that already collected by the craftsmen in Ndolon. Furthermore, we also analyzed 1 sample per-locations of mixed clay-sand materials and ceramic products.
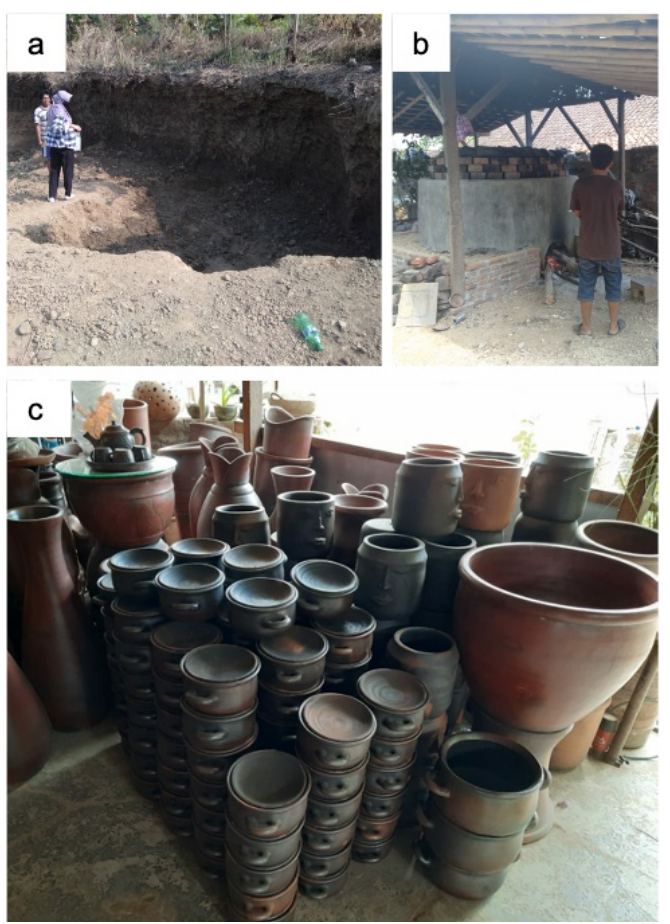

Fig. 2. a. Samples of clay-sized soil derived from the clayquarry in Melikan and Paseban. b. The semi-traditional furnace from concrete and red bricks in Melikan and Paseban. c. Common ceramic products of Melikan and Paseban

All materials from each location of Melikan, Paseban, and Ndolon were analyzed for their 
mineralogical composition using XRD in the Central Laboratory of Geological Engineering Department, Universitas Gadjah Mada. The methods used were bulk and separated clay analyses. The samples preparation for XRD analyses was following Wicaksono et al. [7]. The minerals were determined using JADE software. The last step corrected manually match with JCPDS database.

Furthermore, the ceramic product samples were also observed and analyzed their mineralogical composition under the polarization microscope in Optical Geology Laboratory, Geological Engineering Department, Universitas Gadjah Mada. The samples preparation for petrography analyses was following Setiawan et al. [8]. The abundance of the minerals in the XRD and petrography analyzes were determined qualitatively.

\section{Result and discussion}

\subsection{Physical characteristics}

The final products of the ceramic depend on the material sources and processing. The main steps of making Bayat ceramics were explained in Safitri et al. [3], which are simplified by preparing the raw materials (clay), shaping the products, drying, and firing. In general, Melikan and Paseban ceramic products are identical. The craftsmen in these areas share their clay-sources from the same quarry (Figures $1 \& 2 a$ ).

The ceramics in these areas were firing in the semitraditional kiln, which builds from concrete and red bricks (Figure 2b). Furthermore, the ceramics from these areas have blackish-shine brown color with a smooth surface. The blackish-shine brown color is a unique characteristic of the ceramic products from these areas, are made by a smoke-firing process using mindi or munggur leaves [3, 9]. Without a smoke-firing process, the ceramics from these areas show standard reddish-brown color. The craftsmen from these areas make traditional functional ceramics (i.e., cooking pot, plates, bowls, mug) and decorative ceramics (Figure 2c).

Ceramic products from Ndolon having different clay source location from Melikan and Paseban, which are from Gunung Kidul area. The ceramics in this location were firing in more traditional open system without kiln structure. The firing held on the ground covered by straw and dried leaves (Figure 3a). The result shows light reddish-brown color with irregular dark burnt effect on the surface of ceramics (Figure 3b). The surface of the ceramics is rougher compared to the products from Melikan and Paseban. Furthermore, the craftsmen from Ndolon mostly only make traditional functional ceramics (i.e., stove, cooking pot, bowls).
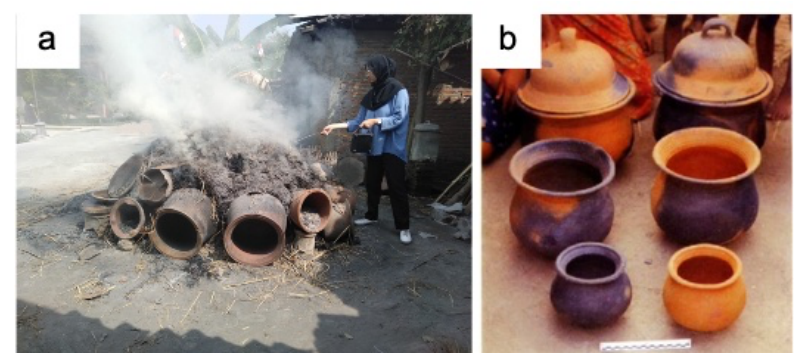

Fig. 3. a. Traditional firing system in Ndolon. b. Ceramic products with open firing systems [9].

\subsection{Mineral composition}

\subsubsection{Clay composition}

Twelve samples were analyzed using XRD, nine from Melikan and Paseban, and three samples from Ndolon (Table 1). The material types of the samples were claysized soil derived from quarry, mixed between clay and sand, and ceramic products. The XRD analyses reveal that the first material of clay-sized soil derived from the quarry in Melikan and Paseban compose of quartz, albite, halloysite, smectite, and kaolinite in all samples. Some samples show plagioclase, amphibole, and pyrite (Table 1). Quartz, albite, and amphibole are commonly found in low-grade metamorphic rock provenance, while plagioclase is commonly found in igneous rock. These results are in agreement with the lithology in West Jiwo Hills, which compose of low-grade metamorphic rocks and igneous intrusions (Figure 1) $[4,5]$.

Table 1. Resume of XRD analyses bulk and clay methods.

\begin{tabular}{|c|c|c|c|c|c|c|c|c|c|c|c|c|c|}
\hline \multirow[b]{2}{*}{ No } & \multirow[b]{2}{*}{ Sample No } & \multirow[b]{2}{*}{ Location } & \multirow[b]{2}{*}{ Type } & \multicolumn{10}{|c|}{ Composition } \\
\hline & & & & $\mathrm{Qz}$ & $\mathrm{Ab}$ & $\mathrm{Pl}$ & Amp & $\begin{array}{l}\text { Am. } \\
\text { Sil }\end{array}$ & Hal & $\mathrm{Lau}$ & Sme & Kal & Pyr \\
\hline 1 & NIS 1M* & Melikan & Quarry clay & $\bullet$ & & $\square$ & & & $\square$ & & $\square$ & $\square$ & \\
\hline 2 & NIS $2 M^{*}$ & Melikan & Quarry clay & $\bullet$ & ○ & & $\square$ & & $\square$ & & $\square$ & $\square$ & \\
\hline 3 & NIS $3 M^{*}$ & Melikan & Quarry clay & $\bullet$ & $\square$ & & $\square$ & & $\square$ & & $\square$ & $\square$ & $\square$ \\
\hline 4 & NIS 5M & Melikan & Clay & - & & & & & & & & $\square$ & $\square$ \\
\hline 5 & NIS 3P & Paseban & Clay & $\bullet$ & ० & & $\square$ & & $\square$ & & $\square$ & $\square$ & $\square$ \\
\hline 6 & NIS $1 \mathrm{~N}$ & Ndolon & Clay & $\bullet$ & & $\circ$ & & & & & $\square$ & $\square$ & \\
\hline 7 & NIS 6M & Melikan & Mix Clay-Sand & $\bullet$ & ० & & $\square$ & & $\square$ & & $\square$ & $\square$ & $\square$ \\
\hline 8 & NIS 1P & Paseban & Mix Clay-Sand & - & & $\circ$ & & & $\square$ & $\square$ & $\square$ & $\square$ & \\
\hline 9 & NIS 2N & Ndolon & Mix Clay-Sand & $\bullet$ & & $\bullet$ & & & & & $\square$ & $\square$ & \\
\hline 10 & NIS A & Melikan & Ceramic & $\bullet$ & ० & & $\square$ & $\square$ & $\square$ & $\square$ & & & \\
\hline 11 & NIS B & Paseban & Ceramic & $\bullet$ & ० & & $\square$ & $\square$ & $\square$ & $\square$ & & $\square$ & \\
\hline 12 & NIS C & Ndolon & Ceramic & $\circ$ & & $\bullet$ & $\square$ & $\square$ & $\square$ & & & & $\square$ \\
\hline \multicolumn{14}{|c|}{ Remark } \\
\hline
\end{tabular}


Furthermore, the appearance of pyrite indicates that the source provenance experienced hydrothermal alteration. Setiawan et al. [5] and Idrus et al. [10] confirmed that the igneous rocks in Jiwo Hills experienced hydrothermal alteration and skarnization. Other minerals of halloysite, smectite, and kaolinite are considered as common low-temperature clay minerals that might be developed during weathering processes [11].

The clay-sized soil from Ndolon has simple compositions of quartz, plagioclase, smectite, and kaolinite (Table 1). Quartz is a common mineral that can present in other provenances, while plagioclase might be derived from igneous rock provenance. As mentioned before, smectite and kaolinite are considered as common low-temperature clay minerals that might be formed by weathering processes

\subsubsection{Mixed clay-sand composition}

The second material is mixed between clay and sand. The sand was added and mixed with the clay to increase the strength of the ceramics during firing. The ratio between sand and clay in Melikan and Paseban is 1:10 [3]. The XRD analyses show that the second material from Melikan and Paseban has a composition of quartz, albite, halloysite, smectite, kaolinite in all samples. Some samples show plagioclase, amphibole, laumontite, and pyrite (Table 1). Clearly, a different result is shown by the appearance of laumontite mineral in the second material composition. The laumontite was possibly added from the sand. The craftsmen bought the sand from the sand-gathered community, which was obtained from the channel bar of Mundu River in Brakal, Wedi, Klaten [3]. The laumontite commonly formed in the hydrothermal system (under low temperature $\left(<220^{\circ} \mathrm{C}\right)$, neutral $\mathrm{pH}$ hydrothermal condition, low $\left.\mathrm{fCO}_{2}\right)$, and in low-grade regional and thermal metamorphism [11]. Both forms of the laumontite are possibly found in this location, especially in the West Jiwo Hills (Figure 1), where the sand and clay were collected. The laumontite might be derived from the hydrothermal alteration related to dioritic and gabbroic intrusions and low-grade metamorphic rocks of the basement complex $[4,5,10]$.

Meanwhile, the XRD analyses of the second material from Ndolon reveal no different composition from the first material of clay-sized soil, which are quartz, plagioclase, smectite, and kaolinite (Table 1). The sand was collected from Sekarbolo River with a mixing ratio between sand and clay is $1: 1$.

\subsubsection{Ceramic composition}

The third material of ceramic products from Melikan and Paseban was analyzed with XRD and petrography analyses. The resume of petrography analyses can be seen in Table 2. Based on the XRD analyses, the ceramic from Melikan and Paseban compose of quartz, albite, amphibole, amorphous silica, halloysite, and laumontite. One sample shows kaolinite (Table 1; Figures $4 \mathrm{a} \& 4 \mathrm{~b}$ ). While petrography analyses show a more detailed composition of mono- and polycrystalline quartz, plagioclase, clay, opaque mineral, pyroxene, hematite, and rock fragment of phyllite. Some samples show amphibole and biotite (Table 2, Figures $5 a-5 d)$.
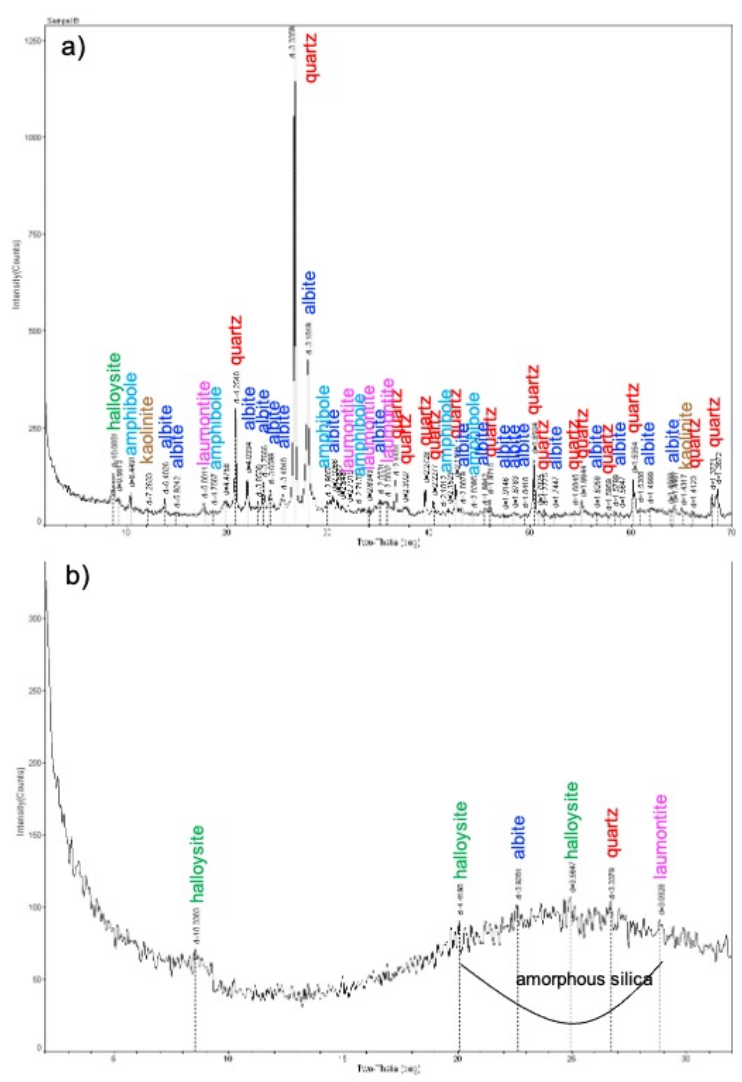

Fig. 4. Peak representative of XRD analysis ceramic product from Melikan or Paseban a. bulk and b. clay methods.

Table 2. Resume of petrography analyses in ceramic products.

\begin{tabular}{|c|c|c|c|c|c|c|c|c|c|c|c|c|c|c|}
\hline \multirow{2}{*}{ No. } & \multirow{2}{*}{ Sample No } & \multirow{2}{*}{ Location } & \multicolumn{12}{|c|}{ Composition } \\
\hline & & & $\mathrm{mQz}$ & $\mathrm{pQz}$ & $\mathrm{Bt}$ & $\mathrm{Pl}$ & $\mathrm{Hbl}$ & Cly & Opq & Px & Hem & Chc & And & Phy \\
\hline 1 & NIS A & Melikan & o & $\bullet$ & & $\square$ & & $\bullet$ & 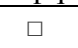 & $\square$ & $\square$ & & & o \\
\hline 2 & NIS B & Paseban & $\square$ & o & $\square$ & $\square$ & & $\bullet$ & $\square$ & $\square$ & o & & & $\square$ \\
\hline 3 & NIS C & Dolon & & & $\circ$ & $\bullet$ & ○ & $\bullet$ & $\square$ & 0 & ○ & $\square$ & ○ & \\
\hline \multicolumn{3}{|c|}{ Remark } & \multicolumn{12}{|c|}{ Abbreviation } \\
\hline - & \multirow{2}{*}{\multicolumn{2}{|c|}{$\begin{array}{l}\text { Abundance }(>25 \%) \\
\text { Moderate }(5-25 \%)\end{array}$}} & \multirow{3}{*}{\multicolumn{3}{|c|}{$\begin{array}{l}\text { mQz: monocrystalline } \\
\text { hornblende; Cly: clay } \\
\text { chalcedony: And: lithic }\end{array}$}} & & Qz: & lycry & ine & $\mathrm{tz} ; \mathrm{B}$ & bioti & Pl: & iocl & $\mathrm{Hbl}:$ \\
\hline o & & & & & & ine & Opc & paq & ninera & Px: & roxer & Hem: & nemat & Che: \\
\hline$\square$ & \multicolumn{2}{|l|}{ Rare $(<5 \%)$} & & & & & & $\mathrm{p}$ & & & & & & \\
\hline
\end{tabular}


The amorphous silica found in XRD analysis might be a new mineral formed by the firing process, which indicates temperature $700-800{ }^{\circ} \mathrm{C}$ [12]. The presence of mono- and poly-crystalline quartz, biotite, and phyllite fragments (Figure 5d) from the petrography analyses in the ceramic from Melikan and Paseban clearly indicate that the provenance is from low-grade metamorphic rocks. However, other minerals such as plagioclase and pyroxene might indicate that the provenance is not only from metamorphic rocks but also igneous rocks. Both possible provenances are found as outcrops in West Jiwo Hills [4, 5]. Furthermore, opaque mineral and hematite might be derived from provenance that experienced hydrothermal alteration or oxidation process.
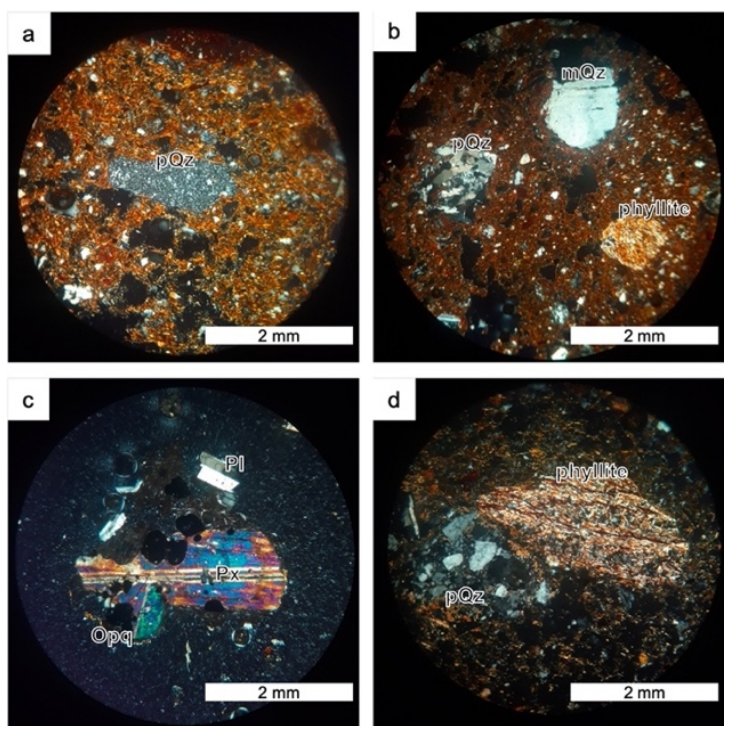

Fig. 5. Representative petrographical analysis of ceramic product from Melikan and Paseban show composition of $\mathbf{a}$. and b. mono- (mQz) and poly-crystalline quartz (pQz); c. clinopyroxene (Px), plagioclase $(\mathrm{Pl})$, opaque mineral (Opq); and d. lithic phyllite.

The ceramic product from Ndolon were also analyzed in XRD and petrography. Based on the XRD analyses (Table 1; Figures 6a \& 6b), ceramic from Ndolon have a composition of quartz, plagioclase, hornblende, halloysite, pyrite, and amorphous silica. Similar to the ceramic from Melikan and Paseban, the amorphous silica might be a new mineral formed by the firing process, which indicate temperature $700-800{ }^{\circ} \mathrm{C}$ [12].

Meanwhile, the petrography analyses reveal that the ceramic composition is biotite, plagioclase, clay, opaque minerals, pyroxene, hematite, chalcedony, and rock fragment of andesite (Table 2; Figures 7a-7d). The presence of andesite rock fragments, plagioclase, and pyroxene suggests a strong indication that the provenance of ceramic in Ndolon is derived from igneous or volcanic rocks (Figures $7 \mathrm{a} \& 7 \mathrm{~b}$ ). This is in agreement with the information from the craftsmen in Ndolon that the clay-quarry is located in the southern part of Ndolon (Gunung Kidul area), which possibly compose of weathered igneous or volcanic rocks from the Kebo-Butak Formation (Figure 1).

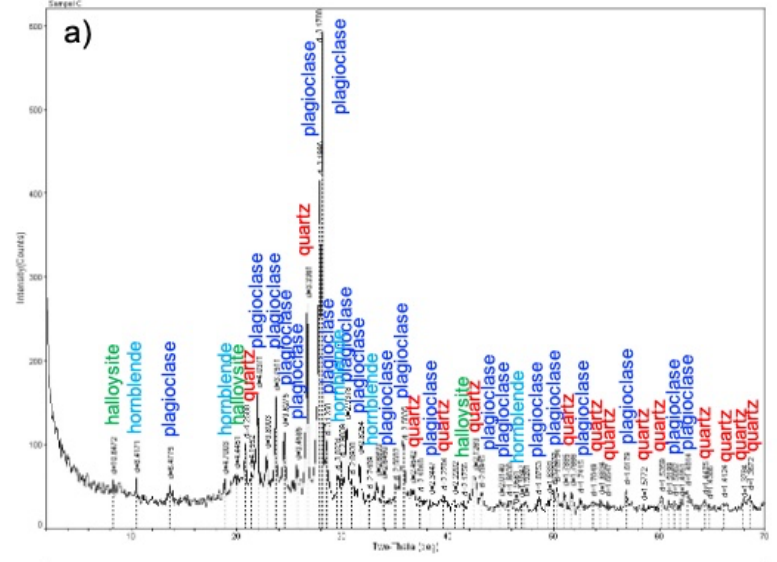

b)

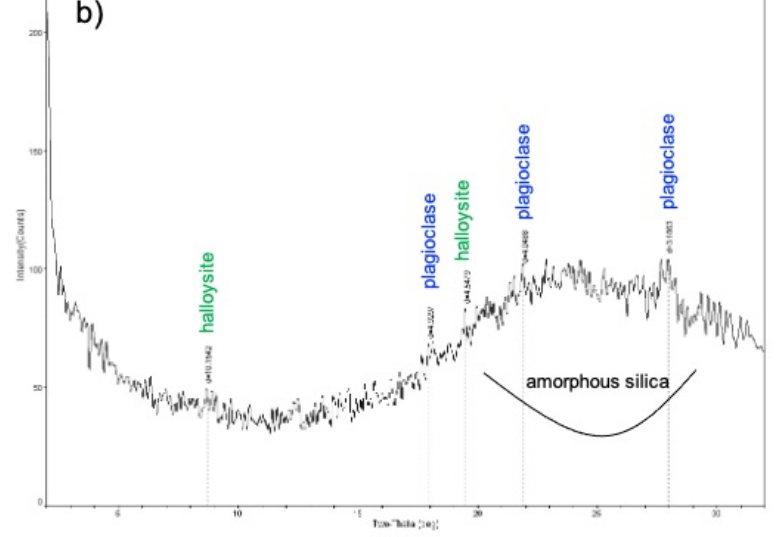

Fig. 6. Peak representative of XRD analysis ceramic product from Ndolon a. bulk and b. clay methods.

Furthermore, chalcedony (Figure 7d) formed where silica deposition is very rapid, and generally at less than $190^{\circ} \mathrm{C}$, though rarely it can be formed at higher temperature as amorphous silica $\left(700-800{ }^{\circ} \mathrm{C}\right)$ [12]. Therefore, the chalcedony could be formed during the firing processes or simply highly-saturation silica condition from the provenance.
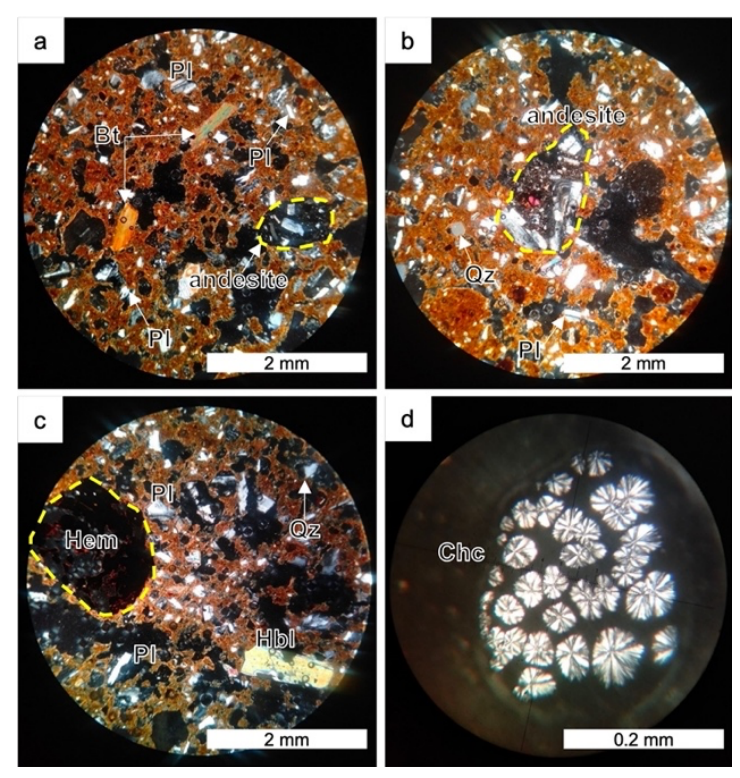

Fig. 7. Representative petrographical analysis of ceramic product from Ndolon compose of a. biotite (Bt), plagioclase $(\mathrm{Pl})$, and clinopyroxene $(\mathrm{Px})$; b. lithic andesite, quartz $(\mathrm{Qz})$, and plagioclase $(\mathrm{Pl})$; c. lithic hematite $(\mathrm{Hem})$, hornblende (Hbl); and d. chalcedony (Chc). 


\section{Suggestion and recommendation}

Historically, the ceramic home industry in Bayat developed 600 years ago [2]. Understanding the characteristics and compositions of clay material source of ceramic in Bayat can be used to determine other clay source location or quarry that have similar characteristics to current clay-materials. This further process requires geochemical and geological mapping studies of potential clay-sources in Bayat and the surrounding area. The identification of the composition in the ceramic also provides qualitative information of the formation temperature, for example, the presence of amorphous silica formed at $700-800{ }^{\circ} \mathrm{C}$ [12]. The technique and temperature of firing in the kiln have been studied for generations. It is necessary to conduct a more in-depth study related to whether the firing temperature is optimum or not to produce a better quality of ceramic. This process requires further experimental studies of heating clay-materials in the laboratory and directly measuring the firing process in close or open kilns.

\section{Conclusion}

Based on the XRD and petrography analyses, the clay minerals of ceramic products from Melikan and Paseban are halloysite, smectite, and kaolinite, while Ndolon is smectite and kaolinite. Mono- and poly-crystalline quartz with a lithic fragment of phyllites were found in Melikan and Paseban ceramic. The ceramic from Ndolon is rich in plagioclase and has a composition of lithic andesite.

Clay provenance of ceramic products from Melikan and Paseban might be derived from weathered lowgrade metamorphic and igneous rocks from West Jiwo Hills. While from Ndolon might be derived from weathered igneous or volcanic rocks from Kebo-Butak Formation.

The amorphous silica that found in all the ceramics from Melikan, Paseban, and Ndolon might be formed by the firing process of $700-800{ }^{\circ} \mathrm{C}$.

We would like to thank Bayat ceramic home industry communities in Melikan, Paseban, and Ndolon, and Klaten Agency for Regional Development (Bappeda) for their assistance during interviews and fieldwork. This research was financially supported by the Ministry of Research and Higher Education of Indonesia under the RTA program and Collaboration Community Service (PKM) Grant from Engineering Faculty, Universitas Gadjah Mada.

\section{References}

1. Y. Hartanto, S.P. Gustami. Sosiohumanika. 3, 427438 (2003), in Bahasa

2. P. Yustana. J. Penelitian Seni Budaya. 6, 14-32 (2014), in Bahasa

3. W. Safitri, T.H. Retnowati, B. Prihadi. Adv. Soc. Sci., Ed. Hum. Res. 444, 34-40 (2020)

4. D.H. Barianto, U. Margono, S. Husein, M.I. Novian. Geological map of Wonosari Quadrangels,
Jawa (1408-31), Scale 1:50,000 (Geology Research and Development Centre of Indonesia, 2017)

5. N.I. Setiawan, Y. Osanai, C. Prasetyadi, Seminar Nasional Kebumian, 6. 11-23 (2013)

6. C. Prasetyadi. Evolusi tektonik Paleogen Jawa bagian Timur, (Dissertation, unpubls., Institut Teknologi Bandung, 2007), in Bahasa

7. D. Wicaksono, N.I. Setiawan, W. Wilopo, A. Harijoko. Seminar Nasional Kebumian. 10, 18641880 (2017), in Bahasa

8. N.I. Setiawan, Sariyanto, A.A. Saputro. Seminar Nasional Kebumian. 7, 378-388 (2016), in Bahasa

9. D.C. Pakarti. Teknik Putaran Miring dan Perkembangan Keramik Bayat Klaten, (Skripsi, unpubls., Universitas Sebelas Maret, 2012), in Bahasa

10. A. Idrus, I.W. Warmada, B. Junitia. Seminar Nasional Kebumian. 6, 37-47 (2013)

11. G.J. Corbett. Epithermal $\mathrm{Au}-\mathrm{Ag}$ and porphyry $\mathrm{Cu}$ $A u$ exploration, (Short course manual, unpubls, 2017)

12. M.M. Haslinawati, K.A., Matori, Z.A. Wahab, H.A.A. Sidek, A.T. Zainal. Int. J. Basic Appl. Sci. IJBAS, 9, 22-25 (2009) 